\title{
Conflicting Role of Land Office and Forestry Department: A Comparative Discussion Regarding to Forest Offences Prevention in Malaysia
}

\author{
Muhammad Uzair Azizan, Tham Sikh Bing, Maryanti Mohd Raid, Mohammad \\ Tahir Sabit Mohammad, Khadijah Hussin, Megat Mohd Ghazali Megat Abd \\ Rahman and Muhammad Izuan Nadzri
}

Department of Real Estate, Faculty of Geoinformation and Real Estate, Universiti Teknologi Malaysia , 81310, Skudai, Johor Bahru, Johor

\begin{abstract}
This article study the discrepancy between theory and practice, especially the roles play by Land Office and Forestry Department in term of overlapping of power and penalties between Land Office and Forestry Department especially the forest on the state land leading to susceptibility in monitoring and enforcement system. The whole empirical works took place in the Central Region of Peninsular Malaysia namely as Negeri Sembilan. The total area of permanent reserved forest in that state is 155,531 hectares including the Permanent Reserved Forest Johol which was selected as the case study in this research. An exploratory research design was adopted in this research. Therefore, in-depth interviews have been done with officers from the Land Office and Forestry Department regarding their role and powers in monitoring and enforcement system to combat forest offences in Permanent Reserved Forest Johol. While data collected was analyzed using the descriptive analysis method. Content analysis was used to identify the similarities and dissimilarities of acts that empower Land Office and Forestry Department to taking action against forest offences. Theoretically, there are overlapping powers occurs between Land Office and Forestry Department identified in National Land Code 1965 and National Forestry Act 1984 in terms of arrestment of the forest offenders and seized their equipment. However, penalties imposed by both acts are very different. Practically, both authorities have divided their responsibility and power accordingly to avoid overlapping. Issues and challenges that faced by them have been found and most of them are similar. There should be an amendment to the acts in terms of the penalty imposed by both authorities. The penalty stated in both acts should be synchronized or the related sections be removed if the authorities do not implement it practically to avoid overlapping and conflicting of action imposed between two acts.
\end{abstract}

Keywords: state land, forest, forest offences, penalties, monitoring, enforcement, overlapping of power

Citation: Azizan, M.U., Bing, T.S., Raid, M.M., Mohammad, M.T.S, Hussin, K., Rahman, M.M.G.A., and Nadzri, M.I. (2017). Conflicting Role of Land Office and Forestry Department: A Comparative Discussion Regarding to Forest Offences Prevention in Malaysia. Jurnal Ilmu Lingkungan, 15(1), 11-19, doi:10.14710/jil.15.1.11-19

\section{Introduction}

During the twenty first century, countries in all continents have begun to realize the importance of forest for sustainable species in future. However, forest mass destruction has become a new phenomenon especially in high biodiversity location in the tropics namely, Malaysia. Countries around the world are concerned about global warming and its effect. The increased temperature of the earth has caused natural disasters. Hurricanes, droughts and floods are getting more frequent and unpredictable in several countries. Therefore, the earth needs to be cool to expand the Earth lifespan. Preservation of the forest is one of the important ways to reduce the impact of the global warming. For instance example, with nurturing food based agriculture is in high demand; new land explorations for supply were the only viable option. For 20 years (1992-2012), the trend of both agriculture increment and forest destruction was at a correlating rate of $6 \%$ vs $-5 \%$ respectively (R2 $=0.7156)$ as shown in Figure $1(\mathrm{a})$. This indicate the conversion from forested to other land use is likely due to the need for more space. Moreover, report for wood based export by Food and Agriculture Organization (FAO) in 1992 (595636 MT) compared in 2012 (1235858 MT), show the destruction has increased staggeringly with $52 \%$ (640222 MT). With such an alarming rate, thus call for full attention and action by the designated party. 


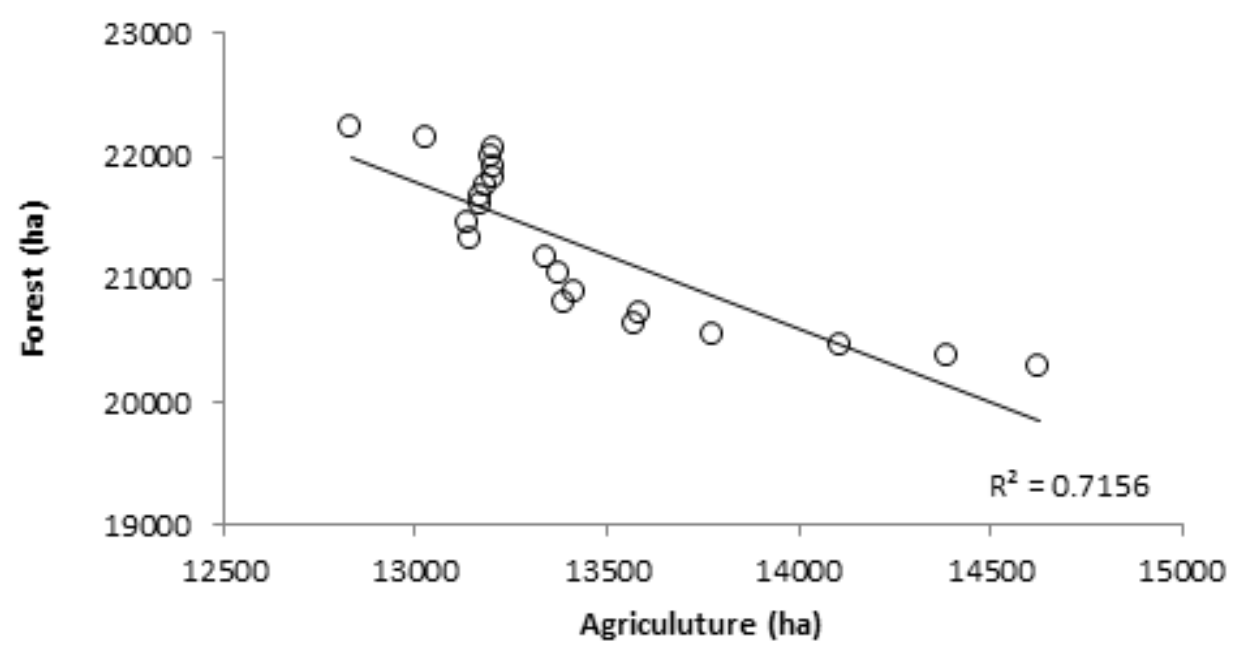

Figure 1 (a): Declination of Malaysia Forest Area versus Agriculture Area

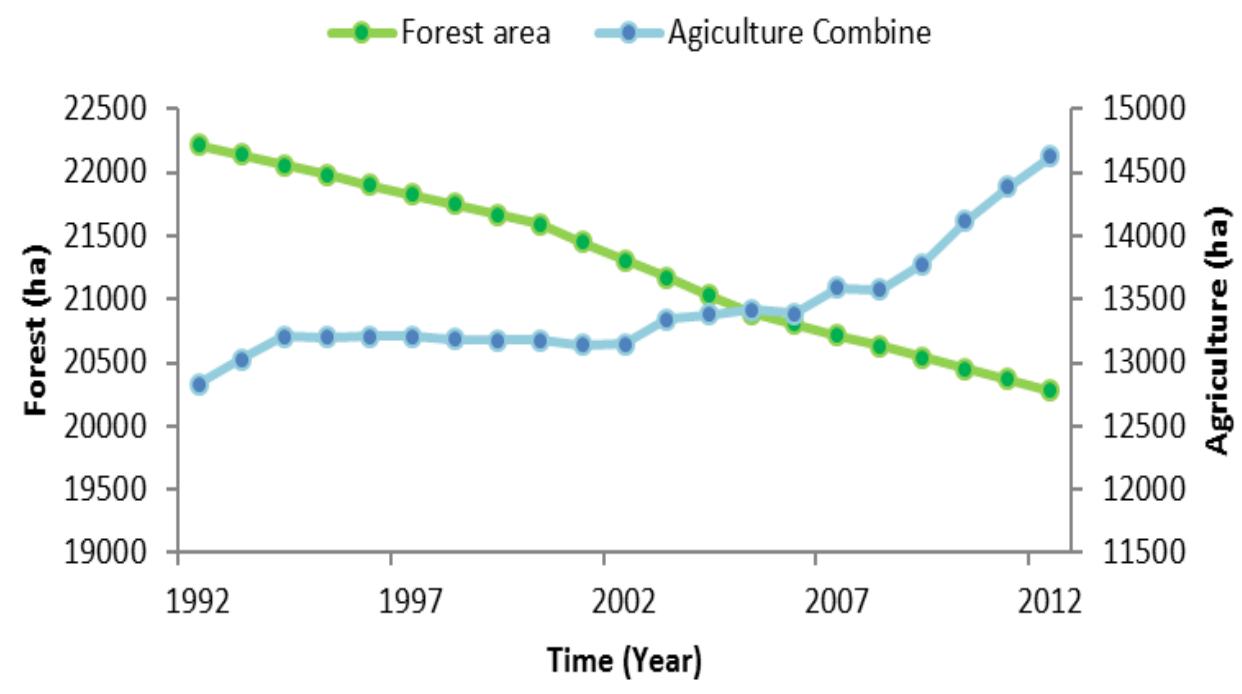

Figure 1 (b): Malaysia Forest Declination Trend since 1992--2012

The forest is a valuable treasure that needs to be protected. If a forest in a country is loss, the nation would lose the place where people can breathe fresh air, habitat for unique of plants and animals and even the place for people to enjoy nature in the rapid development world. The forest has to be preserved. Thus, to avoid the destruction of the forest, every proposal or blueprint for development purposes needs to be considered carefully to make sure that the importance of forest preservation to socio-economic will not be affected.

Laurance (2007) and Hansen et al. (2013) reported that, forest in Malaysia is destroyed rapidly compared to other Asian countries. Moreover, McMorrow and Talip (2001) and Butler (2014) mentioned that Malaysia is one of the 14 major deforesting countries with over 250,000 hectares deforested annually particularly in Sarawak coast that are being stripped even faster. This situation has proved that the rate of forest destruction in Malaysia is increasing since year 2007 . One way to protect the forest is through law enforcement and authority monitoring to prevent forest offences from happening. However, forest offences are still occurred which destruct forest reserve.

There are still many illegal occupiers or forest offenders who cause damage to the forest. This illegal activity caused by forest offences have to be curbed immediately because of its impact on the environment. Thus, this article attempt to study the discrepancy between theory and practice, especially the roles play by Land Office and Forestry Department. The issue raised in this article is forest offences still occur despite of heavy penalties after the amendment of the acts was made. The questions are namely: (i) Is it because of the conflict of the laws to empower Land Office and Forestry Department to enforce the law or the conflict of power between these authorities caused them to hold their action against the forest offences? (ii) Is it because of weak in monitoring and enforcement system and if it is right, then how we can improve?. 
Azizan, M.U., Bing, T.S., Raid, M.M., Mohammad, M.T.S, Hussin, K., Rahman, M.M.G.A., and Nadzri, M.I. (2017). Conflicting Role of Land Office and Forestry Department: A Comparative Discussion Regarding to Forest Offences Prevention in Malaysia. Jurnal IImu Lingkungan,15(1),11-19, doi:10.14710/jil.15.1.11-19

\section{Forest offences: An overview}

Global Forest Resources Assessment (FRA) 2010 defined forest as a large area of a land covered with more than 0.5 hectares with trees more than 5 meters height and tree canopy covering more than 10 percent or trees able to reach these thresholds in-situ. This excludes the land that is predominantly under agricultural or urban land use. FRA 2010 also stated that forests cover 31 percent of the total land area in the world.

Forest covering more than 4 billion hectares globally which corresponds to an average of 0.6 hactares per capita. Countries like the Russian Federation, Brazil, Canada, United States of America and China are signified as most forest-rich countries and they are account for more than half of the total forest area in the world (FAO, 2010). Meanwhile, other several countries have no forest at all, and an additional of 54 countries in the world has less than 10 percent forest of their total land area.

Malaysian Timber Council (2008) draws our attention in 2006 that the total area of land in Malaysia comprise of 32.95 million hectares, of which 24.60 million hectares $(74.7 \%)$ are classified as total area under tree cover. Out of these, 18.5 million hectares are forested area and 6.25 million hectares are other tree crops. However, 8.96 million hectares (36.42\%) of the total area under tree cover are found in Sarawak while 4.41 million hectares $(17.93 \%)$ in Sabah and 11.23 million hectares (45.65\%) are found in Peninsular Malaysia.
According to Smith (2002), the term of "illegal forest activities" referred to a broad definition that includes many illegal activities particularly logging. It is more than just harvesting, but it is also include transporting, processing and trading (Smith, 2002). Brack and Hayman (2001) mentioned that illegalities may occur while transporting process, including illegal processing and export, miss-declaration to customs, avoidance of taxes and other monies. In brief, illegal forest activities include all illegal acts associated with forest ecosystems, forest industries, and timber and non-timber forest products. It also includes the establishment of illegal rights to the land and corrupt activities used to acquire forest concessions.

However, illegal logging has no single definition. In a general sense, Brack and Hayman (2001) explained that illegal logging occurs when the logging activity has violated of national laws timber. This includes almost any illegal act that may occur between the periods of tree planting, harvested, transported, bought or sold-in to the hands of the consumer (Rosenbaum, 2003).

Forest offence is an act that is against the law that done in the forest or also known as forest crime. Official Forestry Department Peninsular Malaysia (2015) website shows that forest offences in Peninsular Malaysia can be grouped into three different categories as shown in Figure 2 below.

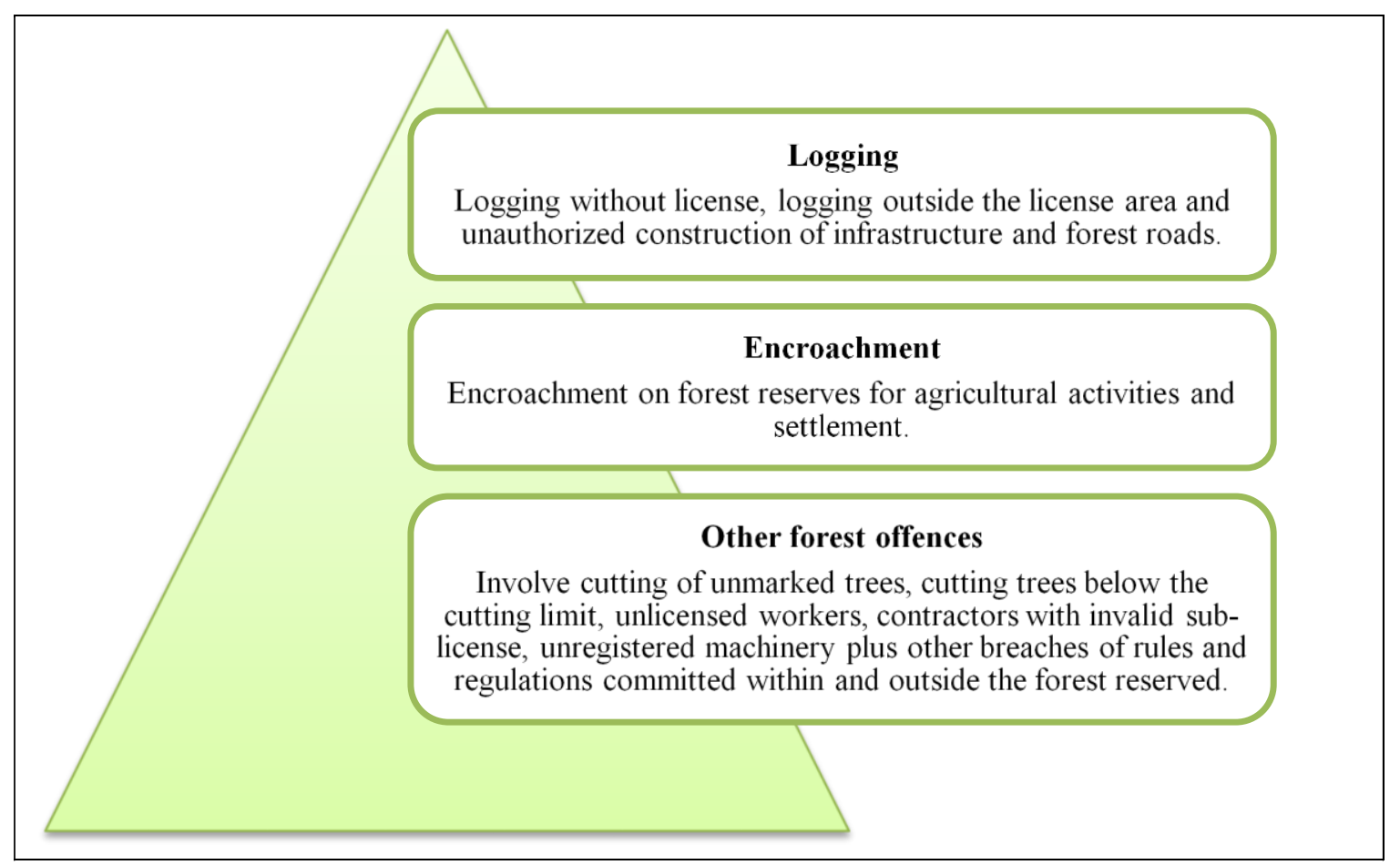

Figure 2: Categories of forest offences (FDPM, 2003).

The implementation of the forestry policies primarily through the provisions of the forest laws enacted under three regions namely as National Forestry Act 1984 for Peninsular Malaysia, Forest 
Ordinance 1958 for Sarawak and Forest Enactment 1968 for Sabah. The other related regulations that affect the forestry policies for Peninsular Malaysia include the Land Conservation Act 1960, Environmental Quality Act 1974, National Parks Act 1980, Protection of Wildlife Act 1972, National Land Code 1965, Aboriginal Peoples Act 1954, Occupational Safety and Health Act 1994 and Forest Rules 1985.

National Forestry Act 1984 for Peninsular Malaysia was revised in 1992 to incorporate several new elements including the importance of forest law enforcement. It emphasized that the State Governments through their respective State Director Forestry must judicially implement the National Forest Act 1984 (Revised 1993) to ensure the sustainable forest resource management and conservation are practiced and implemented.

The National Forestry Act 1984 was enacted to provide the administration, management and conservation matters for forestry in the States of Malaysia. However, an amendment was inserted to impose severe penalties for illegal logging as well as involving the Armed Forces and Police to assist the Forestry Departments during the enforcement of illegal logging, timber theft and encroachments.

National Land Code (1965) is based on the Torrens System and came into effect on 1st January 1966 as basis to administer land in Peninsular Malaysia where it is to provide a practical way of land administration in the country (Zakaria and Hussin, 2013). Based on National Land Code (Act 56 of 1965), it is an act to amend and consolidate the laws relating to land and land tenure, the registration of title to land and of dealings therewith and the collection of revenue. Therefore, and a uniform land system within the States of Johore, Kedah, Kelantan, Malacca, Negeri Sembilan, Pahang, Penang, Perak, Perlis Selangor, Terengganu, and the Federal Territory of Kuala Lumpur, and for purposes connected therewith.

Table 1: Hierarchy of departments with their functions, power and acts that referred.

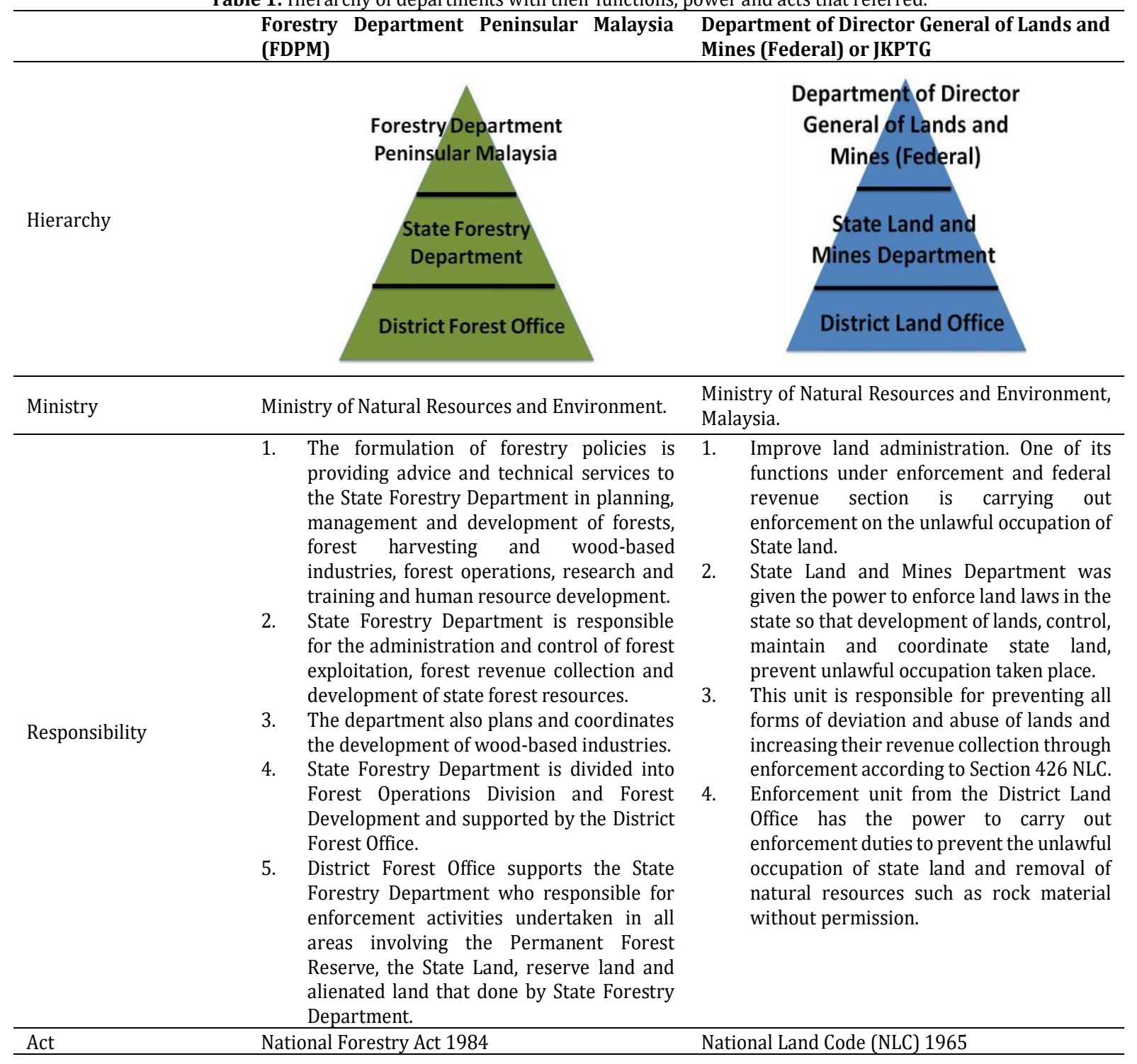


Azizan, M.U., Bing, T.S., Raid, M.M., Mohammad, M.T.S, Hussin, K., Rahman, M.M.G.A., and Nadzri, M.I. (2017). Conflicting Role of Land Office and Forestry Department: A Comparative Discussion Regarding to Forest Offences Prevention in Malaysia. Jurnal Ilmu Lingkungan,15(1),11-19, doi:10.14710/jil.15.1.11-19

Table 2: Similarities comparison between acts that empower Land Office and Forestry Department to prevent forest offences

\begin{tabular}{|c|c|c|}
\hline Agency & Land Office & Forestry Department \\
\hline Acts & National Land Code 1965 & National Forestry Act 1984 \\
\hline $\begin{array}{l}\text { Similarities of } \\
\text { sections }\end{array}$ & $\begin{array}{l}\text { No person shall cut or removes any timber or } \\
\text { produce on or from such land from any state } \\
\text { land, reserved land or mining land without } \\
\text { lawful authority under section } 425(1)(c)\end{array}$ & $\begin{array}{l}\text { No person shall take any forest produce from a } \\
\text { permanently reserved forest or a State land } \\
\text { unless under the authority of a License or by any } \\
\text { other written law under section 15(1) }\end{array}$ \\
\hline
\end{tabular}

No person shall extract removes, transports or permits the extraction of rock material from any land which include Permanent Reserved

"Rock Material" includes guano, rock, peat, sand and soil upon any land. Forest without lawful authority section 426 (1)

No person shall remove any forest produce from any alienated land, land held under a temporary occupation licence, mining land; or reserved land unless he is the holder of a removal licence under section 40 (1)

"Forest produce" includes guano, peat, and rock, sea-sand, river-sand, seashells, shells and surface soil when found in or brought from a permanently reserved forest.

\begin{tabular}{|c|c|}
\hline $\begin{array}{l}\text { Similarities of } \\
\text { Enforcement }\end{array}$ & $\begin{array}{l}\text { Arrest any person found committing or } \\
\text { attempting to commit or abetting the } \\
\text { commission of an offence and seize any vehicle, } \\
\text { tractor, agricultural implement or other thing } \\
\text { whatsoever which he has reason to believe was } \\
\text { used or is being in the commission of an offence } \\
\text { under Section } 426 \mathrm{~A} \text {. }\end{array}$ \\
\hline
\end{tabular}

Arrest without warrant any person whom he has reason to believe to have committed a forestoffence and seize any thing that he considers it necessary to seize in relation to the evidence required to establish the commission of any such offence under Section 88

Table 3: Dissimilarities comparison between the acts that empower Land Office and Forestry Department to prevent forest offences

\begin{tabular}{ll}
\hline Agency & Land Office \\
\hline Acts & National Land Code 1965 \\
\hline Penalty & $\begin{array}{l}\text { For section 425(1), a fine not exceeding ten } \\
\text { thousand Ringgit, or incarceration for a } \\
\text { term not exceeding one year, or to both. }\end{array}$ \\
2. & $\begin{array}{l}\text { For section 426, a fine not exceeding fifty } \\
\text { thousand Ringgit, or incarceration for a } \\
\text { term not exceeding five years, or to both. }\end{array}$ \\
3. $\begin{array}{l}\text { Section } 426(2), \text { any person convicted of an } \\
\text { offence under this section may be ordered to } \\
\text { pay to the State Authority, in addition to any } \\
\text { fine imposed on the conviction, } \\
\text { compensation equal to the value of the } \\
\text { rock material in question, and of any timber } \\
\text { felled or damaged in the course of its } \\
\text { extraction. }\end{array}$
\end{tabular}

Forestry Department

National Forestry Act 1984

1. For sections 15 and 40, fine not exceeding five hundred thousand Ringgit and to incarceration for a term that shall not be less than one year but shall not exceed twenty years.

2. Any person convicted of an offence under this section may, in addition to any penalty imposed on the conviction, be ordered to pay, in respect of any forest produce unlawfully taken, to the State Authority

a) A sum not exceeding ten times the royalty, premium and Cess;

b) A sum not exceeding ten times the value of such forest produce; and

c) Any other charges payable, and any sum ordered to be so paid shall be recoverable as if it were a fine so imposed.

\begin{tabular}{lll}
\hline $\begin{array}{l}\text { Area of } \\
\text { enforcement }\end{array}$ & State land, reserved land and mining land & $\begin{array}{l}\text { Permanent reserved forest, state land, } \\
\text { alienated land; land held under a temporary } \\
\text { occupation license; mining land; or reserved } \\
\text { land }\end{array}$ \\
\hline $\begin{array}{l}\text { Scope of } \\
\begin{array}{l}\text { Enforcement on } \\
\text { the state land }\end{array}\end{array}$ & $\begin{array}{l}\text { Land Status or unlawful activities other than } \\
\text { forest produce. }\end{array}$ & Forest Produces \\
\hline
\end{tabular}




\section{Methodology and case study}

An exploratory research design was adopted in this research. Therefore, in-depth interviews have been done with five officers each from Land Office and Forestry Department regarding their powers in monitoring and enforcement system to combat forest offences in Permanent Reserved Forest Johol. All of the respondents selected are at the state level. The data collected was analyzed using the descriptive research method.
The case study has taken place in Permanent Reserved Forest Johol, Negeri Sembilan, Malaysia. Negeri Sembilan is located in the Central Region of Peninsular Malaysia with an area of $665,374.77$ hectares. The total area of permanent reserved forest in that state is 155,531 hectares including the Permanent Reserve Forest Johol.

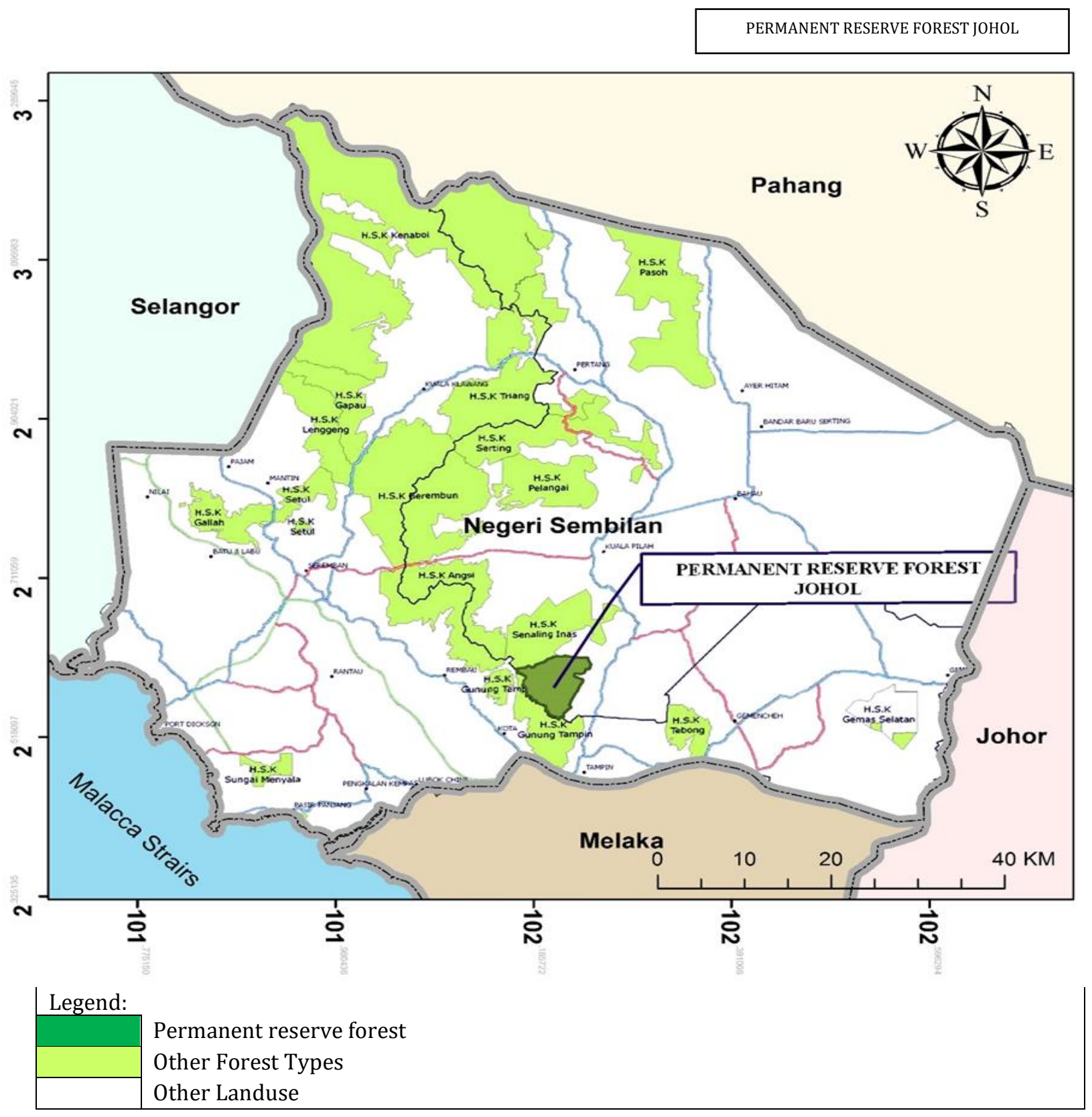

Figure 3: Permanent Reserved Forest Johol, Negeri Sembilan, Malaysia

\section{Result and Findings}

4.1. Sections in the Acts that Empower Land Office and Forestry Department to Prevent Forest Offences

According to Section 425(1)(c) under NLC 1965, the enforcement unit from Land Office have the power to arrest forest offenders and seize their equipment if they try to remove timber or forest product from the state land, mining land, or reserved land which include permanent reserved forest". 
Azizan, M.U., Bing, T.S., Raid, M.M., Mohammad, M.T.S, Hussin, K., Rahman, M.M.G.A., and Nadzri, M.I. (2017). Conflicting Role of Land Office and Forestry Department: A Comparative Discussion Regarding to Forest Offences Prevention in Malaysia. Jurnal IImu Lingkungan,15(1),11-19, doi:10.14710/jil.15.1.11-19

Based on the referred acts and an informal interview with the respondents, this research was able to find similarity of powers in both departments where they have right to arrest the forest offenders whom remove timber or forest products from the state land and seize their equipment according to National Land Code (NLC) 1965 Section 425(1)(c) and 426 while National Forestry Act 1984 Section 15(1) and Section $40(1)$.

Besides, enforcement unit from Land Office have the power to monitor and enforce the forest on state land and reserved land including forest reserve which is one part of the reserved land according to Section 425 NLC 1965. However, after the introductory of the National Forestry Act in 1984, Land Offices are no longer intervenes the monitoring and enforcement task in the permanent reserved forest.

\subsection{Perceptions of Authorities from Lands Office on the Role to Prevent Forest Offences \\ However, the respondent has reported that} there are no forest offences occurs during his services. Moreover, he has stressed that they usually concentrate on the enforcement on idle state land or unlawful extraction or removal of rock material rather than forest offences on the state land.

He also added that "Before introduction of the National Forestry Act 1984, Land Office have the power to monitor and enforce in the forest of state land, mining land or reserved land which include Permanent Reserved Forest due to the section 425 provided in National Land Code 1965".

Nevertheless, after the introduction of the National Forestry Act 1984, Land Office is no longer focuses their task on the monitoring and enforcement in permanent reserved forest. They rather just emphasize on the unlawful activities other than forest product in the forest of the state land.

\subsection{Perceptions of Authorities from Forestry Department on the Role to Prevent Forest Offences}

In the case of the forest on state land or alienated land, Forestry Department only intervenes when it is about the removal of the forest product. Land Office will be responsible for monitoring and enforcing the law on forest offenses other than the removal of forest product. For instances, occupy, or erect any building, or clears, ploughs, digs, encloses or cultivates, encroachment and other activities on the state land or alienated land are under the jurisdiction of Land Office.

Until the date of interview, there are no forest offenders or illegal occupiers imprisoned because of forest offences as stated under the National Forestry Act. If forest rangers managed to arrest the forest offenders during their operation, the Forestry Department usually will refer to the legal adviser where they will analyze the case and decide whether they should take the forest offenders to court or sue them based on which section in the act.

Upon enforcing the appointed law, Negeri Sembilan Forestry Department always cooperates with other agencies such as Royal Malaysia Police (PDRM), Malaysian Anti-Corruption Commission (SPRM), District Land Office, Department of Orang Asli Affairs (JAKOA) and other related agencies to handle series of forest offences.

\subsection{Analysis of the Issues and Challenges that faced by authorities from Land Office and Forestry Department}

Based on Table 3, the writer can summarize that most of the issues and challenges faced by the enforcement unit from both Land Office or Forestry Department are almost identical. Hence, they should integrate and try to solve the issues or challenges together by exchanging the information, training skills or use the same equipment in hybrid. However, there are also some issues or challenges faced by one department only, for example, allocating a portion of money in the budget to give reward and involvement of aborigine people in the forest offences faced by Forestry Department only. This is due to the focus of enforcement unit from Land Office is not to the forest of state land but on prohibited activities on the idle state land and illegal extraction of rock material on the state land.

Table 3: Summary of Issues and Challenges that faced by Both Department

\begin{tabular}{lcc}
\hline & & \multicolumn{2}{c}{ Respondents } \\
\cline { 2 - 3 } Issues and Challenges & Land Office & Forestry Department \\
\hline 1. Shortage of staffs & $\sqrt{ }$ & $\sqrt{ }$ \\
2. Lack of Technology or Equipments & $\sqrt{ }$ & $\sqrt{ }$ \\
3. Shortage of Transport & $\sqrt{ }$ & $\sqrt{ }$ \\
4. Lack of training skills among staffs & $\sqrt{ }$ \\
5. Safety of the enforcement unit & $\sqrt{ }$ \\
6. Devoid of budget to give reward & $\sqrt{ }$ \\
7. Service "TONTO" which is tracking by people & & $\sqrt{ }$ \\
8. Involvement of aborigine people in the forest offences & & \\
\hline
\end{tabular}




\section{Discussion}

The analysis has shown that Land Office and Forestry Department practically separate their responsibility and power. The Land Office will not be monitoring and enforcing the permanent reserved forest while Forestry Department focusing on the forest products only from the state land. Meanwhile, Land Office also can concentrate on the illigal activities other than forest products on the state land. Several questions arise after the analysis where Land Offices does not fully utilize the acts that authorise them to monitor and enforce. Amendment of the acts should be made either to synchronize the penalty from both acts or delete the related sections if the authorities does not implement it practically. Although according to the interviewed respondent, the prosecutor will decide to sue the forest offenders depend on the penalty of both acts whether which section will provide heavier punishment. However, it is odd if the enforcement unit can monitor and enforcing the law according to the provisioned acts but not permitting them to issue the penalty.

Most of the issues and challenges faced by both authorities are similar. Therefore, they should come to an understanding to solve the issues or challenges faced by them. The forest offences will happen again if there are no decisive action taken by the authorities to look into these matters properly. For example, both departments can share the same equipment, exchange information or attend training skills together.

The safety of the enforcement unit also is one of the challenges faced by the Land Office and Forestry Department. As mentioned above, the people who involved in the forest offences are the people who might have a criminal record which can expose the staff in the enforcement unit to danger position. It is hardly impossible for the enforcement unit to apprehend the forest offenders if they are more advanced in skills and equipment compared to the enforcement unit.

Granting that the Land Office and Forestry Department have the power to monitor and enforce the act, they usually prefer not to intervene other department's jurisdiction to avoid conflict of power. The cooperation between both Land Office and Forestry Department is essential as they are the authorize parties to monitor and enforce the law. Besides, it will be a great loss to the state government or even to the public if the authorities failed to protect the forest from logging, encroach or any illegal activity. This will indirectly decrease the revenue of the state government gained from forest productions and the environment particularly flooding and landslides.

\section{Conclusion}

This research provides a comparative discussion of the role of the Land Office and Forestry Department to prevent forest offences in Malaysia. Based on the evidence from the interview with both 18 authorities, Land Office and Forestry Department monitor and enforce during their routine based on their own acts regulations. Even though in theory, there is overlap of power between both departments where they have the power to arrest forest offenders and seize their equipment that used to remove forest produce on the state land, however they unable to issue the penalty. Practically they seperate their power and responsibility where: (i) Forestry Department can only take action involving removal of forest product on the state land while; (ii) Land Office focus on the land status or unlawful activities other than removal of forest produces if the forest located on the state land. Thus, an improvement in the monitoring and enforcement system of Land Office and Forestry Department at Negeri Sembilan is crucial as the cases of forest offences are increasing especially in the reserved forest of state land. Amendment of the acts should be made either to synchronize the penalty from both acts or delete the related sections if the authorities do not implement it practically. Most of the issues and challenges by both authorities are similar, therefore they should come to an understanding to solve the issues or challenges faced by them. Forest offences can cause by many factors. There are maybe also some related human factor such as the attitude of a public servant who did not care for this crime, corruption among enforcer and incompetence officer that tremendously increase. Thus, the government particularly those from both departments should be aware of these issues for better monitoring and enforcement system in the future.

\section{References}

Brack, D., \& Hayman, G. (2001). Intergovernmental Actions on Illegal Logging. Paper presented at the Conference on Forest Law Enforcement and Governance, London.

Ceroboh Hutan Simpan Johol mula disiasat. (2010). Utusan Malaysia. Retrieved September 10, 2010; from http://www.utusan.com.my/utusan/info.asp?y=2010\&dt=0 $603 \&$ pub=Utusan_Malaysia\&sec=Dalam_Negeri\&pg=dn_25. htm

Dewi Adharina Mohd Yunus (2002). Kajian penguatkuasaan terhadap pencerobohan tanah kerajaan dalam kawasan Rizab Melayu. Kajian kes : Pejabat Tanah Daerah Johor Bahru. Universiti Teknologi Malaysia, Skudai.

Food and Agriculture Organization of the United Nations, FAO (2010), Global Forest Resources Assessment 2010 Main report, Rome.

Forestry Department Peninsular Malaysia. Retrieved September 10, 2015 from http://www.forestry.gov.my/

Hansen, M. C., Potapov, P. V., Moore, R., Hancher, M., Turubanova, S. A., Tyukavina, A., ... \& Townshend, J. R. G. (2013). Highresolution global maps of 21st-century forest cover change. science, 342(6160), 850-853.

ITTO (1992). ITTO guidelines for sustainable management of the natural tropical forest. ITTO Policy Development Series 1. 18 p.

Jabatan Perhutanan Negeri Sembilan (2008). Laporan Tahunan Jabatan Perhutanan Negeri Sembilan 2008. Cetak Ratu Sdn. Bhd.

Jabatan Perhutanan Negeri Sembilan (2009). Laporan Tahunan Jabatan Perhutanan Negeri Sembilan 2009

Kerajaan negeri memberi amaran kepada mereka yang tidak bertanggungjawab. Jangan Ceroboh. (2010, June 3). Sinar Harian. p. 1. 
Azizan, M.U., Bing, T.S., Raid, M.M., Mohammad, M.T.S, Hussin, K., Rahman, M.M.G.A., and Nadzri, M.I. (2017). Conflicting Role of Land Office and Forestry Department: A Comparative Discussion Regarding to Forest Offences Prevention in Malaysia. Jurnal Ilmu Lingkungan,15(1),11-19, doi:10.14710/jil.15.1.11-19

Lands and Mines Office Negeri Sembilan. Retrieved September 10, 2015 from http://www.ns.gov.my/ptgns/

Malaysia (1965). National Land Code. Act 56

Malaysia (1984) National Forestry Act. Act 313

Malaysia destroying its forests three times faster than all Asia combined. (2011). Telegraph UK. Retrieved September 10, $2015 . \quad$ From http://www.telegraph.co.uk/news/earth/earthnews/8295 896/Malaysia-destroying-its-forests-three-times-fasterthan-all-Asia-combined.html

Malaysia Timber Council. Retrieved September 10, 2015 from http://www.mtc.com.my/

McMorrow, J. \& Talip, M. A. (2001). The decline of forest area in Sabah, Malaysia: Relationship to state policies, land code and land capability. Global Environmental Change, 11: 217-230

Butler R. A. (2014, November 29). Former Malaysian chief: Legal logging also 'destructive' of forests. Retrieved September 14, 2015.

Rosenbaum, K., L. (2003). Defining Illegal Logging: What is it, and what is being done about it? (A background paper for the 44th meeting of the FAO Advisory Committee on Paper and Wood Products, May 2003.

Smith, W., (2002). "The global problem of illegal logging”. ITTO Tropical Forest Update, Vol. 10, No. 1, pp. 3-5.

The study reveals rapid deforestation in Malaysia. (2011). Retrieved September 10, 2015 from http://article.wn.com/view/2011/02/02/Study_reveals_ra pid_deforestation_in_Malaysia/

Yong, C. (2006). Forest Governance in Malaysia: A NGO Pespective . Netherlands: Zuidam Uithof, Utrecht.

Zakaria, S. R. A., \& Hussin, K. (2013). Recognition of the Economic Security in the Form of Assurance Fund as a Protection to Landowners and the Economic Stimulator in Malaysia. 